\title{
Biological width: No violation zone
}

\author{
Ashu Sharma, G. R. Rahul, Bhawna Gupta ${ }^{1}$, Mozammil Hafeez ${ }^{1}$ \\ Department of Prosthodontics and Oral Implantology, ${ }^{1}$ House Surgeon, Bangalore Institute of \\ Dental Sciences and Research Center, Bangalore, Karnataka, India
}

\author{
Address for correspondence: \\ Dr. Ashu Sharma \\ Department of Prosthodontics, Bangalore \\ Institute of Dental Sciences and \\ Hospital, 5/3 Hosur Main Road, Opposite \\ Lakkasandra Bus Stop, Wilson Garden, \\ Bangalore - 560027 , Karnataka, India. \\ E-mail:drashu_sharma@yahoo.com
}

\begin{abstract}
Maintenance of gingival health is one of the keys for the longevity of teeth, as well as for the longevity of restorations. The concept of Biologic width has been widely described by periodontists and restorative dentists. An adequate understanding of relationship between periodontal tissues and restorative dentistry is paramount to ensure adequate form, function and esthetics, and comfort of the dentition. While most clinicians are aware of this important relationship, uncertainty remains regarding specific concepts such as biologic width and indications and applications of surgical crown lengthening. These violations lead to complications like gingival inflammation, alveolar bone loss and improper fit of the restorative component. This review gives the wide aspect of the complex question of biologic width and represents an attempt to answer some of the demands in relation to it. The article also discusses the possible methods to assess biologic width, problems that occur after improper margin placement in the periodontium and the alternative procedures for prevention of biological width violation.
\end{abstract}

Key words

Biological width, bermuda triangle, margin placement, periodontal health

\section{INTRODUCTION}

Maintenance of gingival health is one of the keys for the longevity of teeth, as well as for the longevity of restorations. In this context, the biologic width functions as a barrier against the entrance of microorganisms into the internal medium of the periodontal ligament and into the gingival and osseous connective tissue. An adequate understanding of the relationship between periodontal tissues and restorative dentistry is paramount to ensure adequate form, function, esthetics, and comfort of the dentition. While most clinicians are aware of this important relationship, uncertainty remains regarding specific concepts such as the biologic width.

Much ruckus is justifiably made by many clinicians over violating the biologic width in crown margin placement with chronically inflamed tissue around a crown in violation of this sacred region. But what exactly is this

\begin{tabular}{|l|l|}
\hline \multicolumn{2}{|c|}{ Access this article online } \\
\hline Quick Response Code: & Website: \\
\hline ⿴囗十 & www.ejgd.org \\
\cline { 2 - 3 } & \\
\hline
\end{tabular}

so-called biologic width? Why when despite your best efforts to esthetically hide a crown margin in the sulcus, it comes peeking back at you at the next prophylaxis visit? Lets hope what follows helps to clear all those unanswered questions.

\section{NORMAL GINGIVAL ARCHITECTURE}

Gargiulo et al. ${ }^{[1]}$ reported in 1961 a certain uniformity of the dimension of some components of biologic width:

a. Mean depth of the histologic sulcus is $0.69 \mathrm{~mm}$,

b. Mean junctional epithelium measures $0.97 \mathrm{~mm}$ (0.71-1.35 mm),

c. Mean supraalveolar connective tissue attachment is $1.07 \mathrm{~mm}$ (1.06-1.08 mm).

The total of the attachment is therefore $2.04 \mathrm{~mm}(1.77$ to $2.43 \mathrm{~mm}$ ) and is called the biologic width ${ }^{[2,3]}$ essential for preservation of periodontal health and removal of irritation that might damage the periodontium (prosthetic restorations, for example) [Figure 1].

The millimeter that is needed from the bottom of the junctional epithelium to the tip of the alveolar bone is held responsible for the lack of inflammation and bone resorption, and as such the development of periodontitis. The dimension of biologic width is not constant, it depends on the location of the tooth in the alveola, varies 
from tooth to tooth, and also from the aspect of the tooth. Its constancy can only be found in healthy dentition. ${ }^{[1-6]}$

\section{SIGNIFICANCE OF BIOLOGICAL WIDTH}

Biological width is of great significance with respect to restorative dentistry. In the human body, ectodermal tissue serves to protect against invasion from bacteria and other foreign materials. However, both teeth and dental implants must penetrate this defensive barrier. The natural seal that develops around both, protecting the alveolar bone from infection and disease, is known as the biological width. The biological width is also defined as the dimension of the soft tissue, which is attached to the portion of the tooth coronal to the crest of the alveolar bone. ${ }^{[7]}$

\section{EVALUATION OF BIOLOGICAL WIDTH}

To evaluate or determine biological width in clinics we make use of the periodontal probe. The biological width can be identified by probing under local anesthesia to the bone level, referred to as sounding to bone, and subtracting the sulcus depth from the resulting measurement. If this distance is less than $2 \mathrm{~mm}$ at one or more locations, a diagnosis of biological width violation can be confirmed. This measurement must be performed on teeth with healthy gingival and should be repeated on more than one tooth to ensure accurate assessment, and reduce individual and site variations. ${ }^{[7]}$

Kois $^{[8]}$ in 2000, proposed three categories of biological width based on the total dimension of attachment and the sulcus depth following bone sounding measurements. These are normal crest, high crest and low crest. ${ }^{[8,9]}$

\section{Normal crest patient}

In the normal crest patients, the mid-facial measurement is $3 \mathrm{~mm}$ and the proximal measurement ranges from 3 $\mathrm{mm}$ to $4.5 \mathrm{~mm}$. Normal crest occurs approximately $85 \%$ of time. In these cases gingiva tends to be stable for a long term.

\section{High crest patient}

This is an unusual finding in nature and occurs approximately $2 \%$ of the time. There is one area where high crest is seen more often, in a proximal surface adjacent to an edentulous site. In the high crest patient, the mid-facial measurement is less than $3 \mathrm{~mm}$.

\section{Low crest patient}

In the low crest patient group, the mid-facial measurement is greater than $3 \mathrm{~mm}$ and the proximal measurement is greater than $4.5 \mathrm{~mm}$. Low crest occurs approximately $13 \%$ of the time. Traditionally a low crest patient has been described as more susceptible to recession secondary to the placement of an intracrevicular crown margin. ${ }^{[7]}$
Radiographic interpretation is also used to identify interproximal violations of biological width. However, on the mesiofacial and distofacial line angles of teeth, radiographs are not diagnostic because of tooth superimposition. ${ }^{[10]}$ A new radiographic technique called parallel profile radiographic technique (PPR) is used to measure the dimensions of the dental gingival unit (DGU). This technique could measure both the length and the thickness of the DGU with accuracy, as it is simple, concise, non-invasive, and a reproducible method. ${ }^{[8]}$

\section{BERMUDA TRIANGLE VS BIOLOGICAL WIDTH}

The Bermuda triangle is a region in the western part of the North Atlantic Ocean where a number of aircraft and surface vessels are said to have disappeared under mysterious circumstances [Figure 2]. The boundaries of the triangle cover the Straits of Florida, the Bahamas

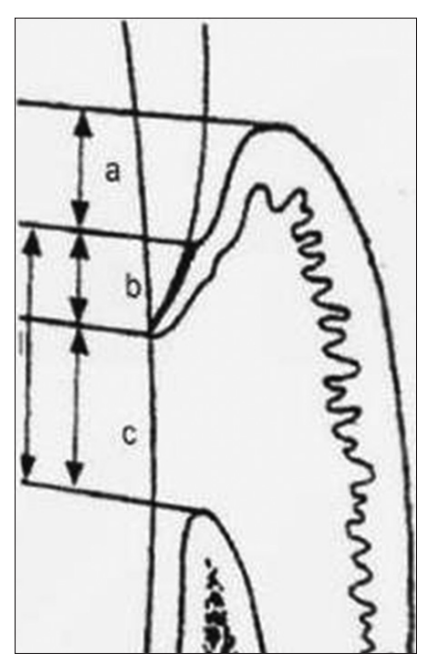

Figure 1: (a) Histological sulcus (0.69 mm), (b) Epithelial attachment (0.97 mm), (c) Connective tissue attachment $(1.07 \mathrm{~mm})$, (d) Biological width $(b+c)$

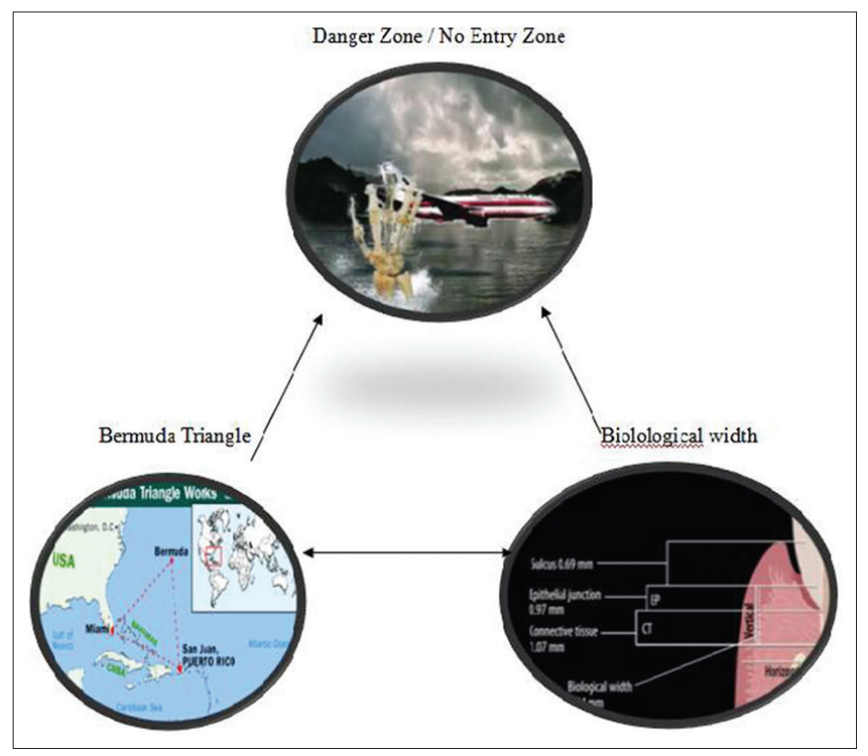

Figure 2: Bermuda triangle 
and the entire Caribbean island area and the Atlantic east to the Azores. The area is one of the most heavily traveled shipping lanes in the world, with ships crossing through it daily for ports in the Americas, Europe, and the Caribbean Islands but people are scared to travel through this region.

In dentistry the area of biological width along with sulcus, around natural teeth or an implant is sometimes called Bermuda Triangle or Devil's Triangle. It extends from gingival crest, with tooth/implant on one side and biological width on the other side. Like the Bermuda triangle, this biological width area is most exploited and misused area in dentistry, by almost all the dentists irrespective of their specialty. Like the Bermuda triangle where a number of aircraft and sea vessels are said to have disappeared, the margins of the prosthetic crowns are extended so much that the dentist loses the access and vision where the margin is actually located in the sulcus region. This leads to many periodontal complications and eventually prosthetic failure.

\section{SIGNS OF VIOLATION OF BIOLOGICAL WIDTH}

If a patient experiences tissue discomfort when the restoration margin levels are being assessed with a periodontal probe it is good indication that the margin extends into the attachment and that a biological width violation has occurred. ${ }^{[5]}$ Subgingival placement of the crown and preparation margins potentially endanger biologic width and lead to periodontal reaction. If the biologic width is violated during the preparation of the tooth there will be no place left for the attachment and this results in the development of attachment loss and pocketing can be observed..$^{[1-18]}$ A problem with restorations of the subgingival margins is the improperly finished and polished margins. Such margins, whether they are produced directly or indirectly, are often everyday findings, especially if it is known that it is almost impossible to ideally finish the margins of crowns and veneers. ${ }^{[19]}$ The most frequent reason for incorrect margins is the impossibility to perform proper casting and/or margin finishing when the margin is already located subgingivally. ${ }^{[20]}$

The deeper the margins lie, the greater is the possibility that it is unpolished. ${ }^{[21]}$ It is precisely these places which represent ideal bacteria colonizing areas at which, the moment it becomes too tight, result in localized inflammation and gingivitis. Oral hygiene maintenance in such places is impossible, clinical signs being chronic inflammatory response and progress of attachment loss.

The signs of biological width violation are: Chronic progressive gingival inflammation around the restoration, bleeding on probing, localized gingival hyperplasia with minimal bone loss, gingival recession, pocket formation, clinical attachment loss, and alveolar bone loss. Gingival hyperplasia is most frequently found in altered passive eruption and subgingivally placed restoration margins..$^{[1]}$ Prosthetics can lead to greater plaque accumulation causing inflammation leading to periodontitis.

\section{CORRECTIONOF VIOLATIONOFBIOLOGICAL WIDTH}

The correction of biological width violations can be done by either surgically removing bone away from proximity to the restoration margin or orthodontically extruding the tooth and thus moving the margin away from the bone. Surgery is the more rapid of the two treatment options. It is also preferred if the resulting crown lengthening will create a more pleasing tooth length. In these situations, the bone should be moved away from the margin by the measured distance of the ideal biologic width for that patient, with an additional $0.5 \mathrm{~mm}$ of bone removed as a safety zone. ${ }^{[8]}$

Gingival recession is a potential risk after removal of bone. If interproximal bone is removed, there is a high likelihood of papillary recession and the creation of an unesthetic triangle of space below the interproximal contacts. If the biologic width violation is on the interproximal, or if the violation is across the facial surface and the gingival tissue level is correct, then orthodontic extrusion is indicated.

The extrusion can be performed in two ways. By applying low orthodontic extrusion force, the tooth is erupted slowly, bringing the alveolar bone and gingival tissue with it. The tooth is extruded until the bone level has been carried coronal to the ideal level by the amount that needs to be removed surgically to correct the attachment violation. The tooth is stabilized in this new position and then treated with surgery to correct the bone and gingival tissue levels. Another option is to carry out rapid orthodontic extrusion whereby the tooth is erupted to the desired amount over several weeks. During this period, a supracrestal fibrotomy is performed weekly in an effort to prevent the tissue and bone from following the tooth. The tooth is then stabilized for at least 12 weeks to confirm the position of the tissue and bone, and any coronal creep can be corrected surgically. ${ }^{[22]}$

\section{ESCAPING BIOLOGICAL WIDTH VIOLATION}

Maynard and Wilson ${ }^{[13]}$ in 1979 divided the periodontium into three dimensions: Superficial physiologic, crevicular physiologic, and subcrevicular physiologic. The superficial physiologic dimension represents the free and attached gingival surrounding the tooth, while the crevicular physiologic dimension represents the gingival dimension from the gingival margin to the junctional epithelium. The subcrevicular physiologic space is analogous to the biologic width described by 
Gargiulo et al. ${ }^{[1]}$ in 1961, consisting of the junctional epithelium and connective tissue attachment. Maynard and Wilson ${ }^{[13]}$ claimed that all three of these dimensions affect restorative treatment decisions and the clinician should "conceptualize" all three areas and the interplay between them and restorative margins. It is said by many researchers that margin placement into the subcrevicular physiologic space should be avoided to prevent the placement of "permanent calculus" beyond the crevice.

In 1984, Nevins and Skurow ${ }^{[23]}$ stated that when subgingival margins are indicated, the restorative dentist must not disrupt the junctional epithelium or connective tissue apparatus during preparation and impressing taking. The researchers recommended limiting subgingival margin extension to $0.5-1.0 \mathrm{~mm}$ because it is impossible for the clinician to detect where the sulcular epithelium ends and the junctional epithelium begins. They also emphasized allowing a minimum $3.0 \mathrm{~mm}$ distance from the alveolar crest to the crown margin. ${ }^{[7]}$

Proper margin placement is also necessary for the prevention of biological width violation. A clinician is presented with two more options for margin placement apart from subgingival location: Supragingival and equigingival (even with the tissue) locations. The supragingival margin has the least impact on the periodontium. The use of equigingival margins traditionally was not desirable because they were thought to train more plaque than supragingival or subgingival margins and therefore result in greater gingival inflammation. There was also the concern that any minor gingival recession would create an unsightly margin display. These concerns are invalid today, not only because the restoration margins can be esthetically blended with the tooth but also because restorations can be completed easily to provide a smooth, polished interface at the gingival margin. From a periodontal viewpoint, both supragingival and equigingival margins are well tolerated. ${ }^{[7]}$

The margin of a crown should generally be placed no closer than $2.5 \mathrm{~mm}$ from alveolar bone. In high crest patient it is not possible to place an intracrevicular margin because the margin will be too close to the alveolar bone, resulting in biological width impingement. When preparing the anterior teeth for indirect restorations it is essential that the dentist should know about the crest category. This allows the operator to determine the optimal position of margin placement and also inform the patient of the long term effects of the crown margin on gingival health and esthetics. ${ }^{[5]}$

Based on the sulcus depth, the following three rules can be used to place intracrevicular margins:

1. If the sulcus probes are $1.5 \mathrm{~mm}$ or less, the restorative margin could be placed $0.5 \mathrm{~mm}$ below the gingival tissue crest
2. If the sulcus probes are more than $1.5 \mathrm{~mm}$, the restorative margin can be placed in half the depth of the sulcus

3. If the sulcus is greater than $2 \mathrm{~mm}$, gingivectomy could be performed to lengthen the tooth and create a $1.5 \mathrm{~mm}$ sulcus. The patient can then be treated as per rule $1 .{ }^{[8,24]}$

Wagenberg ${ }^{[19]}$ concluded that at least $5-5.25 \mathrm{~mm}$ of hard tooth substance above the bone margins is necessary for a correctly prepared restoration placement. Teeth with subgingival caries, fractures, short clinical crowns with or without esthetic deficiencies, and teeth shortened by incomplete exposure of the anatomic crown does not have enough hard tooth surface for correct preparation for restoration. In such cases instead of placing subgingival margins, procedures like crown lengthening and apical flap placement with bone recontouring should be considered, in addition to orthodontic eruption. ${ }^{[7]}$

\section{CONCLUSION}

Finally we can say that the relationship between the periodontal health and the restoration of teeth is intimate and inseparable. The biological width is essential for preservation of periodontal health, which itself is dependent on the properly designed restoration. Restorations with supragingival or equigingival margins should be preferred. If restorative margins need to be placed near the alveolar crest, crown-lengthening surgery or orthodontic extrusion should be considered to provide adequate tooth structure while simultaneously assuring the integrity of the biologic width. Although individual variations exist in the soft tissue attachment around teeth, there is general agreement that a minimum of $3 \mathrm{~mm}$ distance, should exist between the restorative margin and the alveolar bone, allowing for $2 \mathrm{~mm}$ of biologic width space (attachment epithelium and connective tissue above crestal bone) and $1 \mathrm{~mm}$ for sulcus depth.

\section{REFERENCES}

1. Gargiulo AW, Wentz FM, Orban B. Mitotic activity of human oral epithelium exposed to 30 per cent hydrogen peroxide. Oral Surg Oral Med Oral Pathol 1961;14:474-92.

2. Vacek JS, Gher ME, Assad DA, Richardson AC, Giambarresi LI. The dimensions of the human dentogingival junction, Int $\mathrm{J}$ Periodont Rest Dent 1994;14:154-65.

3. Mishkin DJ, Gellin RG. Re: Biologic width and crown lengthening. J Periodontol 1993; 64:920.

4. de Waal H, Castellucci G. The importance of restorative margin placement to the biologic width and periodontal health. Part II. Int J Periodont Rest Dent 1994;14:70-83.

5. Bader JD, Rozier RG, McFall WT, Ramsey DL. Effect of crown margins on periodontal conditions in regularly attending patients. J Prosthet Dent 1991;65:75-9.

6. Orkin DA, Reddy J, Bradshaw D. The relationship of the position of crown margins to gingival health. J Prosthet Dent 1987;57: 421-4. 
7. Nugala B, Kumar BS, Sahitya S, Krishna PM. Biologic width and its importance in periodontal and restorative dentistry. J Conserv Dent 2012;15:12-7.

8. Kois JC. The restorative-periodontal interface: Biological parameters. Periodontol 2000 1996;11:29-38.

9. Robinson PJ, Vitek RM. The relationship between gingival inflammation and resistance to probe penetration. J Periodontal Res 1979;14:239-43.

10. Galgali SR, Gontiya G. Evaluation of an innovative radiographic technique-parallel profile radiography-to determine the dimensions of the dentogingival unit. Indian J Dent Res 2011;22:237-41.

11. Dragoo MR, Williams GB. Periodontal tissue reactions to restorative procedures. Part II. Int J Periodont Restorative Dent 1982;2:34-45.

12. Johnson RH. Lengthening clinical crowns. J Am Dent Assoc 1990;121:473-6.

13. Maynard JG Jr., Wilson RD. Physiologic dimensions of the periodontium significant to the restorative dentist. J Periodontol 1979;50:170-4.

14. Tal H, Soldinger M, Dreiangel A, Pitaru S. Periodontal response to long-term abuse of the gingival attachment by supracrestal amalgam restorations. J Clin Periodontol 1989; 16:654-9.

15. Wilson RD, Maynard G. Intracrevicular restorative dentistry. Int J Periodontics Restorative Dent 1981;1:34-49.

16. Richter WA, Ueno H. Relationship of crown margin placement to gingival inflammation. J Prosthet Dent 1973;30:156-61.

17. Valderhaug J, Birkeland JM. Periodontal conditions in patients
5 years following insertion of fixed prostheses. J Oral Rehabil 1976;3:237-43.

18. Valderhaug J, Ellingsen JE, Jokstad A. Oral hygiene, periodontal conditions, and carious lesions in patients treated with dental bridges: A 15-year clinical and radiographic follow-up study. J Clin Periodontol 1993;20:482-9.

19. Wagenberg BD. Surgical tooth lengthening: Biologic variables and esthetic concerns. J Esthet Dent 1998;10:30-6.

20. Grajower R, Lewinstein I. A mathematical treatise on the fit of crown castings. J Prosthet Dent 1983;49:663-74.

21. Reeves WG. Restorative margin placement and periodontal health. J Prosthet Dent 1991;66:733-40.

22. Potashnick SR, Rosenberg ES. Forced eruption: principles in periodontics and restorative dentistry. J Prosthet Dent 1982;48:141-8.

23. Nevins M, Skurow HM. The intracrevicular restorative margin, the biologic width, and the maintenance of the gingival margin. Int $\mathrm{J}$ Periodontics Restorative Dent 1984; 4:30-49.

24. Freeman K, Bebermeyer R, Moretti A, Koh S. Single-tooth crown lengthening by the restorative dentist: A case report. J Gt Houst Dent Soc 2000;2:14-6.

How to cite this article: Sharma A, Rahul GR, Gupta B, Hafeez M. Biological width: No violation zone. Eur J Gen Dent 2012;1:137-41.

Source of Support: Nil, Conflict of Interest: None declared.

A free application to browse and search the journal's content is now available for iPhone/iPad. 